Session 3470

\title{
An Innovative Program to Support Undergraduate Engineering Students from Underrepresented Groups
}

\author{
Amy E. Monte, Gretchen L. Hein \\ Department of Engineering Fundamentals \\ Michigan Technological University \\ Houghton, MI
}

\begin{abstract}
In the Fall of 2002, the Graduate, Undergraduate Initiative for Development and Enhancement (GUIDE) program was started at Michigan Technological University. GUIDE's major goal is to provide first year engineering students from underrepresented groups with skills to succeed academically. To meet this objective, the program provides first year students with:

- Undergraduate and graduate mentors

- Seminars with Engineering Faculty where various aspects of engineering career options are presented

- Career development workshops to develop interviewing skills, resumés and cover letters

- Academic scholarships to help with tuition expenses (Undergraduate scholars receive an annual scholarship of $\$ 2,500$ for two years; graduate scholars are awarded a $\$ 3,125$ scholarship.)
\end{abstract}

In the Fall, the first year students are placed in teams with a second year student and a Masters student. The sophomore mentor is a person who participated in the GUIDE program the previous year and successfully completed their first year of engineering school. The graduate student mentor provides mentoring to both undergraduates and is the team leader. Throughout the year, these student/mentor teams meet weekly at the seminars and socially. The engineering seminars provide the GUIDE scholars with opportunities to meet faculty from different engineering departments. These contacts are a way for first year students to become acquainted with faculty in an informal setting. They also provide a contact person when students have questions regarding a given discipline. The topics for the seminars focus on different aspects of engineering careers (i.e.: engineering consulting, graduate school, undergraduate research opportunities, managing your career and personal life, working in industry, engineering for social change, engineering in your community). The seminars are informal and students are encouraged to ask questions and to give comments. The career development workshops are designed to give students skills they need to obtain summer internships or co-ops. The income from these jobs helps the students fund their education after they have completed the GUIDE program. This paper details the GUIDE program and outlines how the students have benefited from the program during its first year. 


\section{Introduction}

Going to college is a difficult transition for any first year student. For minorities and women engineering students, attending a university where there are few underrepresented students can cause additional problems and stress, as well as feelings of isolation. ${ }^{1,2}$ Difficulties with the transition to college, when coupled with financial worries, lead to attrition for many of these students. Michigan Technological University's College of Engineering has approximately 3700 students; minorities and women together represent less than $30 \%$ of this population.

Nationally, there is a gap between the retention rates of minority and women students in engineering and non-minority male students. At Michigan Technological University (MTU), the first year retention rate was $76 \%$ for the $1999-2000$ academic year for women, minorities and overall. However, women and minorities comprised only $23 \%$ and $6 \%$, of the student body, respectively. The retention rates for women and minority engineering students from sophomore through senior year at MTU are lower than those for non-minority males, mirroring national trends. ${ }^{3}$ Since women and minorities make up only a fraction of the students in the College of Engineering, it is likely that they must deal with a myriad of social and personal issues such as isolation, campus climate, lack of role models, hesitation in seeking academic assistance, and inadequate financial resources in addition to the demands of a rigorous curriculum. ${ }^{4}$

In the Fall of 2002, the Graduate, Undergraduate Initiative for Development and Enhancement (GUIDE) program was established at MTU. The GUIDE program is funded by the National Science Foundation (DUE-0220500) and is intended to help underrepresented students succeed in engineering. To accomplish this, the GUIDE program provides academic scholarships, undergraduate and graduate mentors, engineering seminars, and career development workshops. These activities help counteract the "three sources of student departure: academic difficulties, the inability of individuals to resolve their educational and occupational goals, and their failure to become or remain incorporated in the intellectual and social life of the institution." Ultimately the GUIDE program will increase the number of technologically prepared workers to meet the increasing demands of American industry.

\section{The GUIDE Program}

GUIDE's major goal is to have students in underrepresented groups succeed academically in their first two years of study by providing financial aid and personal support. After completing the program, they have the skills to find other means of financial support to complete their baccalaureate program. To meet this objective, the program provides students with:

- a mentor team (one first year student, one sophomor student, and one graduate student),

- seminars with engineering faculty where various aspects of engineering are presented,

- career development workshops to develop interviewing skills, resumés and cover letters, and

- academic scholarships to help with tuition expenses (undergraduate scholars receive an annual scholarship of $\$ 2,500$ for two years; graduate scholars are awarded a $\$ 3,125$ scholarship).

Students most frequently leave college at the end of the first year or during the second year with the primary cause of departure being isolation. ${ }^{5}$ While many scholarship programs fund students after they have successfully completed their freshman and sophomore courses, GUIDE supports 
undergraduate students during their critical first two years of college. The program's goal is for these high-risk students to perform well early in their college career so their strong early performance will enable them to obtain alternate educational funding sources (e.g.,co-op and internship positions) during their latter two years of study. In addition to financial assistance, GUIDE provides each new student with two peer mentors, an engineering community, and engineering and career opportunity information. Each aspect of the GUIDE program is described in the following paper.

Mentor Teams: Many universities have upper-class students mentoring new students. Studies show that these mentors provide a support community for the new student while allowing the older student to take some responsibility for the welfare of the new student. ${ }^{5}$ GUIDE organizes students into three tiered mentoring teams. Each first year student is teamed with a sophomore and a graduate student mentor. After the first year, the mentee students become sophomore mentors. Graduate students are selected from the Peace Corps Master's International students in Civil and Environmental Engineering. (MTU has a unique relationship with the U.S. Peace Corps through our Master's International Program (see www.civil.mtu.edu/ jm41/ peacecorp/mipeacecuts.html) that attracts a diverse group of domestic and underrepresented students into MTU's Civil and Environmental Engineering graduate programs. Students take 9 months of coursework at MTU to prepare them for technical and non-technical issues they might encounter as Peace Corps volunteers. This coursework also prepares them for an engineering career upon graduation. After completing their 2 years of Peace Corps service, students return to MTU to write and orally defend their research report that details their volunteer assignment. Students then receive an MS degree in either Civil or Environmental Engineering.) This three tiered mentoring team provides first year students with sophomore mentors who completed their first year at MTU and Graduate mentors who successfully completed their bachelor's degree. The mentor teams are set up according to their interests and disciplines.

In the Fall semester, the mentors meet for training. During this training, the sophomore and graduate student mentors are grouped in their teams to become acquainted. Mentors learn skills to be effective mentors: avoiding roadblocks, empathetic listening, confidentiality, asking questions and giving feedback. Additional topics covered during the training include: university learning centers, counseling services, educational opportunity, and other services on campus. To help students learn about the services available on campus, a scavenger hunt is used. The scavenger hunt combines website information as well as physically locating campus services. It also provides a break from the classroom training and allows mentor teams bonding time. In addition to the training, fun activities are included such as building and testing a ping-pong ball launcher and a pizza lunch. This training gives the mentors a chance to get to know each other and begin building a mentor community (see Figure 1). 

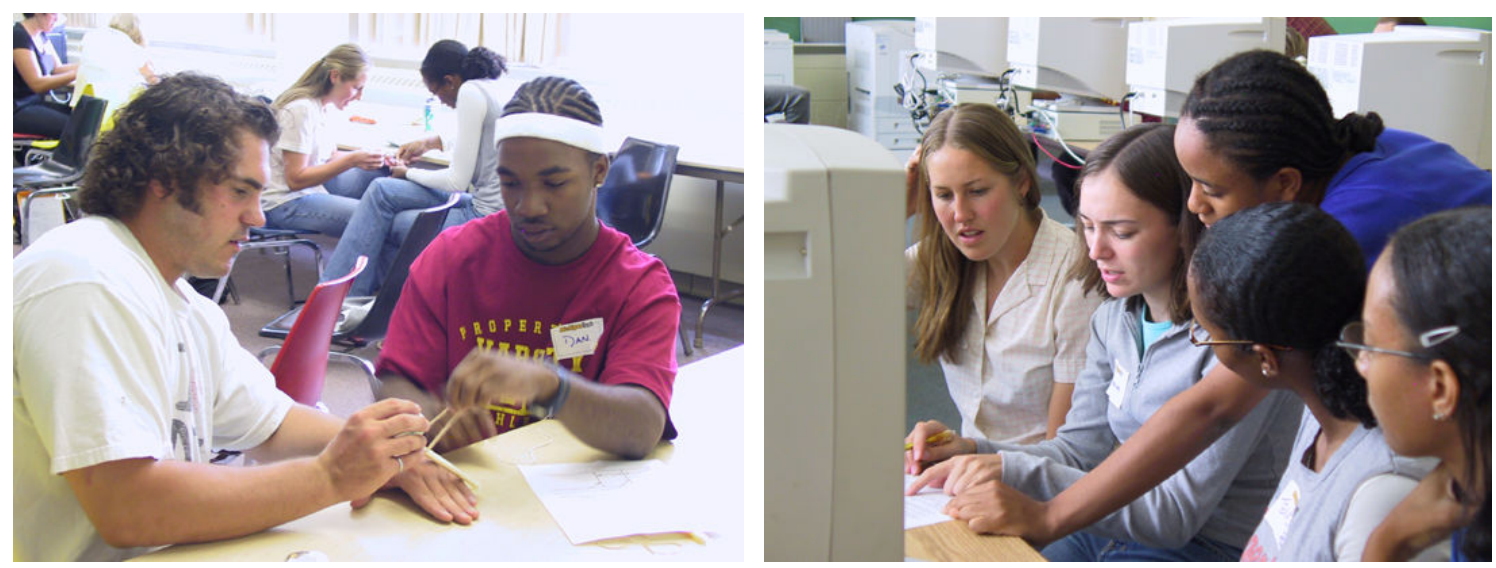

Figure 1: Team building activities during mentor training (ping-pong ball launcher, scavenger hunt).

Engineering Seminars: The GUIDE scholars attend weekly engineering seminars during the Fall semester where they have time to ask questions and discus the engineering topic, career path, or discipline of the speaker. MTU faculty and engineers in the community discuss career and life issues particular to an engineer.

The engineering seminars include topics students should consider while completing their degree. For instance, "Balancing Career and Personal Life" covers issues from having a spouse and family to hobbies and sports and how these decisions affect a person's career. Table 1 lists the engineering seminars that have been offered. Since there is not enough time to cover all engineering topics and disciplines in the Fall, some topics are covered during the Spring career development workshops.

Table 1: Engineering Seminar Topics, Speakers and Departments Represented

\begin{tabular}{|l|l|l|}
\hline Topic & Speaker & Department \\
\hline Master International Program Introduction & Graduate Mentors & Civil \& Environmental Eng \\
\hline What to Expect as a First Year Student & Undergrad Mentors & Engineering \\
\hline The Pros \& Cons of Working in Industry & MaryFran Desrochers & Mechanical Eng Technology \\
\hline UG Leadership/Professional Societies & Student Panel & Student Organizations \\
\hline Attend Career Fair & & Career Center \\
\hline Diversity (or Lack of) in Engineering & Debra Wright & Biomedical Engineering \\
\hline Teaching as a Career Path & Matt Zimmer & High school Math Teacher \\
\hline Graduate School & Michele Miller & Mechanical Engineering \\
\hline Engineering Consulting & Tom Van Dam & Civil \& Environmental Eng \\
\hline Social Activism \& Engineering & Alex Mayer & Geological Eng \& Sciences \\
\hline Undergraduate Research Opportunities & Student Panel & College of Engineering \\
\hline Using Engineering in Village Council & Brett Hamlin & Engineering Fundamentals \\
\hline Engineering Career Options & Sheryl Sorby & College of Engineering \\
\hline The Military as an Engineering Career Option & Glen Archer & Electrical \& Computer Eng \\
\hline Balancing Career and Personal Life & Tammy Haut Donahue & Mechanical Engineering \\
\hline What Can I do with an Engineering Degree? & Jim Mihelcic & Civil \& Environmental Eng \\
\hline Enterprise Program & Mark Plichta & Materials Science and Eng \\
\hline How Engineering Disciplines Overlap & John Gierke & Geological Engineering \\
\hline
\end{tabular}


During Fall 2003 engineering seminars, the focus was on different ways to use an engineering degree. Many of the seminars illustrated how engineering can benefit the community (i.e.: social activism, volunteer activities and community politics). Other seminars involved career planning (i.e.: engineering consulting, graduate school, working in industry). In lieu of faculty speakers, two panel discussions were held regarding undergraduate leadership and research opportunities. In these seminars, students spoke about their leadership roles in student organizations or how they obtained undergraduate research positions. Based on the questions and interactions with the panelists, the panel discussions were well received by the GUIDE scholars.

Career Development Workshops: During Spring semester the career development workshops focus on career enhancement (see Table 2 for topics). The GUIDE scholars meet in the Harold Meese University Career Center to learn how to effectively find and obtain a job. Students create an engineering resumé. Representatives from the Career Center critique the students' resumés. Students participate in mock interviews as well as learn how to write cover letters and thank you letters. In addition, the GUIDE students learn what services are available through the Career Center and how to access them. Throughout these workshops, the scholars work directly with representatives from the Career Center. The purpose of this interaction is for the student to become comfortable with the center and staff.

In addition to the career development workshop, other seminars are held. These include a CoOp/Internship Student Panel and Enterprise Panel. (The MTU Enterprise program allows students to learn about manufacturing and business at the university. Students run business ventures that are sponsored by outside companies. To learn more about this program, see www.enterprise.mtu.edu.) The undergraduate scholars also learn about opportunities for minors, certifications, and studying nationally or abroad. This information helps them create or update their graduation plan and select appropriate classes.

Table 2: Career Development Workshop Topics

\begin{tabular}{|l|l|l|}
\hline Topic & Speaker & Department \\
\hline Career Center Overview, FOCUS, Getting a job... & James Turnquist & Career Center \\
\hline Resumé writing; bring a draft of your resumé & James Turnquist & Career Center \\
\hline Resumé Critique; bring updated resumé & Career Center Staff & Career Center \\
\hline Mock Career Fair & MI Students & Civil \& Environmental Eng \\
\hline Attend Career Fair & & Career Center \\
\hline Cover Letters \& Thank-you Letters & James Turnquist & Career Center \\
\hline Mock Interviews & James Turnquist & Career Center \\
\hline Study Nationally or Abroad, Minors, Certification & Amy Monte & Engineering Fundamentals \\
\hline Graduation Plan, Scheduling for Classes & Amy Monte & Engineering Fundamentals \\
\hline Co-op/Internship & Student Panel & \\
\hline Enterprise Program & Student Panel & \\
\hline
\end{tabular}

\section{Student Requirements for Scholarship}

To remain in the program, students must maintain a GPA of 2.25 or higher, demonstrate financial need, and remain in a technical field of study. In addition, students must participate in the program as described below. 
Undergraduate Students: The requirements for undergraduate scholars in this program are outlined in Table 3 with a total estimated time commitment of 2-3 hours per week. First year students gain academic and social support from their mentors while learning about engineering career opportunities. In one of the engineering seminars, professional engineering societies are invited to meet with the GUIDE scholars to introduce their organization. During the Fall semester, the first year students must join a professional engineering society. To help them decide which to join, students must attend meetings for a minimum of 3 different organizations' meetings. The GUIDE student is expected to continue attending meetings and hold a leadership position in the second year. This requirement provides another source of university involvement for the GUIDE student. Through this experience, the students gain leadership experience necessary for their first engineering job. During the second year, GUIDE scholars attend mentor training with the graduate mentors. The second year student is an important part of the mentoring team because they have the experience from their first year and know the in's and out's of MTU.

Table 3: Undergraduate Scholars Activities for the two years of scholarship support

\begin{tabular}{|c|c|c|}
\hline Year & Semester & Activity \\
\hline \multirow[t]{8}{*}{1} & \multirow[t]{4}{*}{ Fall } & Meet weekly with mentors \\
\hline & & Attend and participate in Engineering Seminars \\
\hline & & Attend meetings in three different professional organizations and join one \\
\hline & & Participate in Semester Evaluation/Review Interview \\
\hline & \multirow[t]{4}{*}{ Spring } & Meet weekly with mentors \\
\hline & & Attend and participate in Career Center Workshops \\
\hline & & Attend one professional society regularly \\
\hline & & Participate in Semester Evaluation/Review Interview \\
\hline \multirow[t]{6}{*}{2} & \multirow[t]{6}{*}{ Fall/ Spring } & Complete mentor training seminar \\
\hline & & Meet weekly with graduate student mentor and first year mentee \\
\hline & & Hold a leadership position in a professional organization \\
\hline & & Attend and participate in Engineering Seminars (Fall) \\
\hline & & Attend and participate in Career Center Workshops as needed (Spring) \\
\hline & & Participate in Semester Evaluation/Review Interview \\
\hline
\end{tabular}

Graduate Student Requirements: Graduate scholars primarily serve as mentors to the undergraduates in the program by providing them with an initial point of contact and a "road map" to academic success. As a mentor, the graduate student mentor familiarizes the mentees with services available on campus before there is a "crisis." The mentor informally monitors student academic progress, and assists them in the successful completion of their courses. In order to be effective mentors, the graduate students attends mentor training.

The graduate mentors attend the Engineering Seminar series during the first semester; the Career Center Workshops in the Spring are available to the mentors but are not required. They participate fully in the semester evaluation/reviews for their mentees each semester. This review also provides an opportunity for the program advisor to evaluate the mentoring skills of the graduate student. In addition, it provides the mentors with the opportunity for review of the program and to let the program advisor know of any concerns they have regarding individual students. A detailed list of graduate scholar responsibilities is outlined in Table 4. 
Table 4: Graduate Scholars Activities for one year of scholarship support

\begin{tabular}{|c|l|}
\hline Semester & Activity \\
\hline \multirow{3}{*}{ Fall } & Complete mentor training seminar \\
\cline { 2 - 2 } & Meet weekly with undergraduate students \\
\cline { 2 - 2 } & Attend and participate in Engineering Seminars \\
\cline { 2 - 3 } & Participate in Semester Evaluation/Review Interview \\
\hline \multirow{3}{*}{ Spring } & Meet weekly with undergraduate students \\
\cline { 2 - 2 } & Attend and participate in Career Center Workshops as needed \\
\cline { 2 - 3 } & Participate in Semester Evaluation/Review Interview \\
\hline
\end{tabular}

GUIDE Social Activities: As part of the program, various social activities are organized. These activities are meant to give the GUIDE scholars an event where they can have fun while building a community. In addition, activities are planned for critical times of the semester, (for example, just before exams when students need a study break). Students are not required to attend these activities, but most do. Examples of activities are: pizza party, pot-luck/cook-out, hockey game and cookie decorating. ${ }^{6}$ Some photos from these events are shown in Figure 2 below.
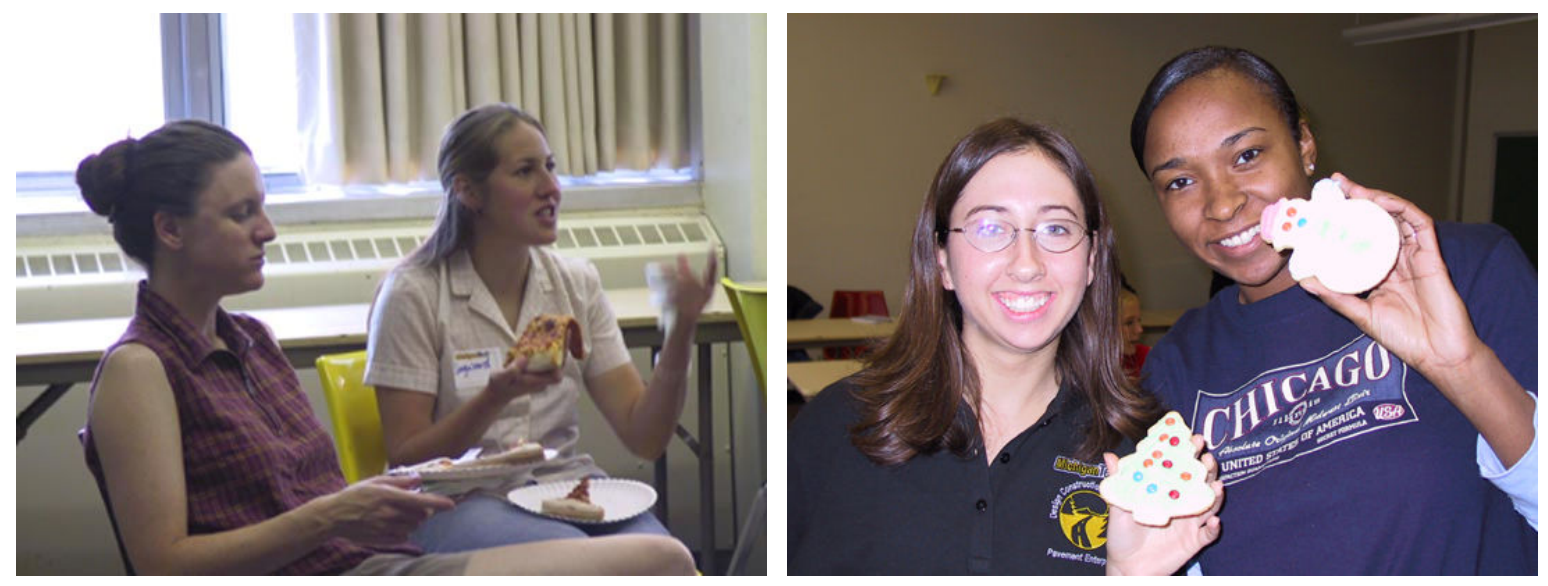

Figure 2: Social activities put on by GUIDE and by the mentor teams (pizza party, cookie decorating).

\section{Application Process}

Because the GUIDE program consists of three groups of students (first year students, undergraduate mentors and graduate mentors), the application process must be different for each group. Applications and program information can be found at the following website: www.geneng.mtu.edu/GUIDE.

First Year Students: During the Spring semester, an invitation letter and a program application are sent to the incoming accepted students who are from underrepresented groups in engineering. Once the applications are received, the data in the application are verified and financial need is assessed. A four person committee of faculty and staff evaluate the applicants. The committee selects up to twelve recipients and at least two alternates. The scholarship recipients are notified and asked to complete an interest survey. This information is used to set up the mentoring teams. 
Undergraduate Mentors: The former first year students become undergraduate mentors after they successfully complete their first year of engineering classes. If they leave the program due to changing to a non-technical major or not meeting the program criteria, there is a need for additional mentors. Therefore, notification letters are sent to current MTU engineering students who meet the eligibility requirements. Once again the applicants are screened for program eligibility. The remaining applicants are evaluated by a faculty committee. The recipients are notified and complete an interest survey.

Graduate Mentors: The graduate mentors are selected from the Peace Corps Masters International Program in Civil and Environmental Engineering. This group is selected to be mentors because of their interest in working with others. The applicants are also evaluated by a faculty committee and complete an interest survey.

\section{Results from the First Year}

Student Demographics: The demographics of the students that participated in the first year of the GUIDE program (2002-2003) are found in Table 5. There were 5 teams of three and one team of four, 2-first year students and 2-graduate mentors, due to the lack of second year students. Of the first year students, $43 \%$ were women and $57 \%$ were minorities. The first year students represented four different engineering majors, one engineering undecided and one business student who started the year in engineering and pre-law. After taking engineering courses and meeting with several academic advisors on campus, this student decided to change to the School of Business and pre-law. Though we did not retain this student in the GUIDE program, he did remain at MTU and therefore we felt his experience with GUIDE was a success. The first year students represented four different engineering majors and one engineering undecided. Overall, the GUIDE students represented six of the nine engineering majors at MTU.

Table 5: Student Demographics for Fall 2002 \& Spring 2003

\begin{tabular}{|l|c|c|c|c|c|c|}
\hline & \multirow{2}{*}{ Scholars } & \multicolumn{2}{|c|}{ Underrepresented Groups } & Average GPA & MTU GPA \\
\cline { 3 - 7 } & Total & \% Women & \% Minority & Fall & Spring & Fall \& Spring \\
\hline First Year & 7 & $43 \%$ & $57 \%$ & 3.05 & 2.74 & 3.04 \\
\hline Undergraduate Mentor & 5 & $60 \%$ & $20 \%$ & 3.13 & 3.11 & 3.06 \\
\hline Graduate Mentor (Fall) & 6 & $17 \%$ & $0 \%$ & 3.85 & -- & -- \\
\hline Graduate Mentor (Spring) & 7 & $29 \%$ & $0 \%$ & -- & 3.77 & -- \\
\hline Number of teams & 6 & \multicolumn{7}{|l}{} \\
\hline
\end{tabular}

The overall GPA for the GUIDE scholars was 3.3 and 3.2 for the Fall and Spring semesters, respectively. For the first year students, the average 2002-2003 GPA was 2.9 which was lower than the MTU average of 3.04. The first year GUIDE student GPA included three students with low performance. First, one student switched to the School of Business and was not doing well in the required engineering courses. The second student received a GPA of 2.05 and was not showing progress towards his/her degree. In this case, since the student did not meet the GUIDE GPA requirement of 2.25 , we decided that the student could not remain in the GUIDE program. The third student struggled in Calculus. This student was on the border of our GUIDE GPA requirements. To remain in the program a second year, the student wrote a letter about what he/she was going to do to improve his/her grades. In addition, the student needed to document grade updates from his/her instructors throughout the Fall semester of the second year. This 
student's grades greatly improved in the Fall of his/her second year (Fall 2003 GPA 2.87).

The demographics for students in the second year (2003-2004) of the program can be found in Table 6. There were 8 teams of three and one team of two (1-sophomore student and 1-graduate student due to the lack of first year scholars). For the second year of the program, we saw larger participant diversity with regard to gender, ethnicity and engineering major. Of the first year students, $88 \%$ were women and $12 \%$ were minority. The undergraduate mentors had $78 \%$ women and $44 \%$ minorities, while the graduate mentors are $56 \%$ women and $22 \%$ minorities. The first year students represented five different engineering majors and one engineering undecided. The overall GUIDE students represented six of the nine engineering majors at MTU, with one student in the School of Biology.

Table 6: Student Demographics for Fall 2003 \& Spring 2004

\begin{tabular}{|l|c|c|c|c|}
\hline & & \multicolumn{2}{|c|}{ Underrepresented Groups } & Average GPA \\
\cline { 3 - 5 } Scholars & Total & \% Women & \% Minority & Fall \\
\hline First Year & 8 & $88 \%$ & $12 \%$ & 3.39 \\
\hline Undergraduate Mentor & 9 & $78 \%$ & $44 \%$ & 3.14 \\
\hline Graduate Mentor & 9 & $56 \%$ & $22 \%$ & 3.58 \\
\hline Number of teams & 9 & \multicolumn{4}{|l}{} \\
\cline { 1 - 5 }
\end{tabular}

The overall GPA for the GUIDE scholars was 3.4 for the Fall 2003 semester. The first year students' GPA was 3.4 which is higher than last year's MTU average of 3.04. One first year student's GPA was 2.46, which is close to the GUIDE programs GPA requirement of 2.25. This student is meeting regularly with the GUIDE coordinators to discuss how classes are going and give grade updates. In addition this student is meeting with the graduate mentors for study sessions in addition to their weekly social activities.

Engineering Topic Seminars: Students were asked to rank the seminars 1-5 (1 = Eliminate, $2=$ Needs Improvement, $3=$ Neutral, $4=$ Good, $5=$ Excellent) and comment or make suggestions for improvement. The results from this survey can be found in Table 7. All of the engineering topics were ranked above average. The comments helped in making improvements to the Fall 2003 seminars. One suggestion was to have more panel discussions. This suggestion was incorporated in the Fall 2003 seminar series. Another suggestion was to rearrange the topics and have the Masters Peace Corps students give their seminar during the beginning of the Fall semester.

Table 7: Engineering Seminars Rating, Spring 2003*, (Rating Scale, $1=$ poor, $5=$ excellent)

\begin{tabular}{|l|c|}
\hline Topic & Rating \\
\hline What can I do with an engineering career? & 3.53 \\
\hline Diversity in Engineering School & 3.62 \\
\hline Balancing Career \& Personal Life & 4.03 \\
\hline How Engineering Disciplines Overlap & 3.24 \\
\hline Peace Corps MI Students & 4.59 \\
\hline
\end{tabular}

* Note: The GUIDE program was established in October 2002 and the seminars, workshops and mentor team meetings began in Spring 2003. The first year of the program was short and not all workshop and seminar topics were presented.

Career Center Workshops: Survey results from the career center workshops can be found in 
Table 8 . All but one topic were rated above a 3.9 on a 5 point scale. The career choices and FOCUS survey seminar was rated 3.2. Since career choice is an important topic, discussions were held on how to improve this workshop. Suggestions were to give students basic FOCUS survey information and the opportunity to meet individually with the career center to discuss their career choices. Some students' suggestions for improvement for Spring 2004 included: more mock interviews, panel discussion with co-op students, how to fill out a job application, how to complete scholarship applications and essays, and how to introduce your self or approach someone at a career fair. These suggestions were incorporated into the Spring 2004 workshops:

- all first and second year students participated in individual mock interviews,

- co-op and internship students presented in panel discussions, and

- a mock career fair helped students practice approaching professionals.

Table 8: Career Development Workshops Rating, Spring 2003*, (Rating Scale, $1=$ poor, $5=$ excellent)

\begin{tabular}{|l|c|}
\hline Topic & Rating \\
\hline Resumé Writing & 4.00 \\
\hline Resumé Critique & 4.54 \\
\hline Cover \& Thank-you Letters & 3.91 \\
\hline Career Choices \& FOCUS survey & 3.20 \\
\hline Mock Interviews & 3.89 \\
\hline Enterprise Program & 3.89 \\
\hline Graduation Plan & 4.06 \\
\hline
\end{tabular}

* Note: The GUIDE program was established in October 2002 and the seminars, workshops and mentor team meetings began in Spring 2003. The first year of the program was short and not all workshop and seminar topics were presented.

One of the goals of GUIDE is to provide first and second year students with the skills needed to find employment to help pay for the remainder of their education. Of the five sophomores to participate in the first year of GUIDE, four obtained work experience. Table 9 outlines each of the student's experience.

Table 9: Engineering work experience for students after the first year of GUIDE.

\begin{tabular}{|l|l|l|l|l|}
\hline$\#$ & Students Major & Experience & Organization & Date \\
\hline 1 & Civil Eng. & Internship & Engineering Resource Associates, Inc. & May-Sep 2003 \\
\hline 2 & Electrical Eng. & Co-Op & Marathon Ashland Petroleum LCC & Jan-May 2004 \\
\hline 3 & Environmental Eng. & Research & MTU - Civil/Environmental Eng. Dept. & May-Aug 2003 \\
\hline 4 & Mechanical Eng. & Internship & Caterpillar Inc. & Jun-Aug 2003 \\
\cline { 3 - 5 } & & Co-Op & John Deere \& Co. & Jun-Dec 2004 \\
\hline
\end{tabular}

Mentor Training: From the mentor training surveys, we found that the mentors felt they had enough information about most topics. They suggested more information on: background of GUIDE, MultiEthnic Programs at MTU, substance abuse, adjusting to college life, and learning centers at MTU. More information on these topics was added to the Fall 2003 training, handout packets and student seminars. Other suggestions were to have more team building activities and more time for the mentors to bond. This resulted in adding the scavenger hunt \& other activities to the Fall 2003 training.

Exit Interviews: All GUIDE students met individually with a GUIDE coordinator for an exit 
interview. Most students felt they had a good team. Still, there were suggestions to improve teams, these included:

1) have teams comprised of introverts and extroverts,

2) give the mentors a list of ideas of activities to do and places to visit, and

3) have more group and team building activities outside the seminars and workshops.

All three of these suggestions were address for Fall 2003.

1) To determine if a student is an extrover or intervert, the following question was added to the personal survey: "When you get together with friends, do you call them or do they call you?"

2) An activities list was handed out to each mentor team. Each activity was given a point value. The mentor teams were encouraged to earn as many points as possible. After two weeks, we discussed what teams did and how many points they earned.

3) Several group and team building acitivities were added: cook-out/pot-luck, attend hockey game, cookie decorating and ice-breakers.

In addition, most teams met more than the minimum of one hour outside of the seminars. Many student teams found a variety of activities that they enjoyed. Several students commented on trying new things due to the encouragement of their team members: going to concerts, watching a broom-ball game, and going snow boarding.

\section{Conclusions}

The GUIDE program at MTU was established to help underrepresented students succeed in their first two years in engineering.

As part of this program undergraduate scholars:

- Form a learning community within their peer group at MTU,

- Develop and maintain relationships with mentors and program advisors,

- Develop learning and life skills that promote academic success,

- Become familiar with the various on-campus academic resources and learning centers,

- Gain exposure to various career paths available to people with engineering degrees,

- Meet and interact with faculty representatives from the engineering departments on campus, and

- Prepare a resumé and become informed about finding, applying for, and interviewing for coop and internship positions.

As part of this program the graduate students:

- Receive training in effective mentoring of protégés,

- Form and maintain a mentoring relationship with an undergraduate students,

- Apply basic mentoring techniques to guide the student through his/her first two years of college, and

- Learn to conduct a professional evaluation/review.

\section{Acknowledgement}

The authors gratefully acknowledge the National Science Foundation (grant number DUE0220500) and MTU, College of Engineering for their support of this work. We also thank the 
engineering faculty and professionals and the Harold Meese Career Center for their seminars and workshops. In addition, we thank Monte Consulting Company for its work on the GUIDE brochure.

\section{References}

[1] Henes, R., Bland, M.M., Darby, J., McDonald, K., January, 1995 "Improving the Academic Environment for Women Engineering Students through Faculty Workshops", The Journal of Engineering Education.

[2] Anderson, V., July/August, 1995, "Identifying Special Advising Needs of Women Engineering Students", The Journal of College Student Development.

[3] Anderson, C., 2000, "Michigan Technological University, 2000-2001 Select Student Support Services Project RISE Proposal". Grant Period: October 1, 2000 through September 30, 2001, Senate Bill No. 967 of 2000.

[4] Hewitt, N.M., Seymour, E., April 1991, "Factors Contributing to High Attrition Rates Among Science and Engineering Undergraduate Majors". Ethonography and Assessment Bureau of Sociological Research, University of Colorado, Boulder, (83-95).

[5] Tinto, V., 1993, “Leaving College: Rethinking the Causes and Cures of Student Attrition”, Second Edition, University of Chicago Press, Chicago, Illinois.

[6] Touton, S., McDonald, C., Monte, A., Hein, G., June, 2004 “Engineers Need Mentors Too!” Proceedings of the 2004 American Society of Engineering Education Annual Conference \& Exposition, American Society of Engineering Education, Salt Lake City, Utah.

AMY E. MONTE - Amy E. Monte is a lecturer in the Department of Engineering Fundamentals at Michigan Technological University. She received her BS and MS in Environmental Engineering at Michigan Technological University. Amy teaches Foundations of Engineering I and II and Engineering and Science Applications in PreCalculus. Amy is also an academic advisor of students in Engineering Undecided and Biomedical Engineering.

GRETCHEN L. HEIN - Gretchen Hein is a lecturer in the Department of Engineering Fundamentals at Michigan Technological University. She received her BSME at Kettering University in Flint, MI and her MSE at Purdue University in West Lafayette, IN. Prior to pursuing her master's degree, she worked as a mechanical engineer at General Motors Corporation. She received her Ph.D. from Michigan Technological University. Gretchen teaches Foundations of Engineering I and II, and Engineering and Science Applications in Pre-Calculus.

Proceedings of the 2004 American Society for Engineering Educations Annual Conference \& Exposition Copyright (C) 2004, American Society for Engineering Education 